\title{
$\alpha$-Amidated peptides derived from pro-opiomelanocortin in normal human pituitary
}

\author{
Mogens FENGER* and Anders H. JOHNSEN \\ Department of Clinical Chemistry, University Hospital, Rigshospitalet, 9 Blegdamsvej, DK 2100 Copenhagen, Denmark
}

\begin{abstract}
Normal human pituitaries were extracted in boiling water and acetic acid, and the $\alpha$-amidated peptide products of pro-opiomelanocortin (POMC), $\alpha$-melanocyte-stimulating hormone ( $\alpha \mathrm{MSH}), \gamma$-melanocytestimulating hormone $\left(\gamma_{1} \mathrm{MSH}\right)$, and amidated hinge peptide (HP-N), as well as their glycine-extended precursors, were characterized by sequence-specific radioimmunoassays, gel-chromatography, h.p.l.c. and amino acid sequencing. $\alpha \mathrm{MSH}$ and $\gamma_{1} \mathrm{MSH}$ constituted $0.27-1.32 \%$ and $0.10-5.10 \%$, respectively, of the POMC-derived products [calculated as the sum of adrenocorticotropic hormone (ACTH)-(1-39), ACTH(1-14) and $\alpha \mathrm{MSH}$ immunoreactivity]. $\alpha \mathrm{MSH}$ and ACTH-(1-14) were only present in non- or monoacetylated forms. Only large forms of $\gamma_{1} \mathrm{MSH}$ and $\gamma_{2} \mathrm{MSH}$ were present in partly glycosylated states. The hinge peptides were amidated to an extent two to three orders of magnitude greater than $\alpha \mathrm{MSH}$ and $\gamma_{1} \mathrm{MSH}$. Most (99\%) of the HP-N was of low molecular mass and consisted mainly of HP-N-30. The remaining part was high-molecular-mass HP-N, probably HP-N-108, although the presence of HP-N-44 could not be completely excluded. These results show that all the possible amidated POMC-related peptides are present in normal human pituitary. It also shows that cleavage in vivo at all dibasic amino acids but one, takes place at the $N$-terminal POMC region; the exception is at the POMC-(49-50) $N$-terminal of the $\gamma \mathrm{MSH}$ sequence. The pattern of peptides produced suggests that the generation of amidated peptides is mainly regulated at the endopeptidase level.
\end{abstract}

\section{INTRODUCTION}

Pro-opiomelanocortin (POMC) contains three main regions, i.e. the central, highly conserved adrenocorticotropic hormone [ACTH-(1-39)] sequence with $\alpha$-melanocyte-stimulating hormone $(\alpha \mathrm{MSH})$ as its $N$-terminus, the $C$-terminal $\beta$-lipotropin, which is partly cleaved to $\gamma$ lipotropin and $\beta$-endorphin, and the $N$-terminal $\gamma \mathrm{MSH}$ containing sequence (Fig. 1). $\gamma \mathrm{MSH}$ and its $N$-terminal extension are highly conserved in mammals showing more than $92 \%$ homology [1-7], while the region between $\gamma_{1} \mathrm{MSH}$ and ACTH-(1-39) is more variable. This latter region has been named hinge peptide or joining peptide [8].

Human POMC (Fig. 1) contains three putative amidation sites, i.e. $X_{1}$-Gly-basic-basic- $X_{2}$ in which $X_{2}$ or basic- $\mathrm{X}_{2}$ is cleaved off by a trypsin-like endopeptidase (the remaining basic residues being removed by a carboxypeptidase B-like enzyme $[9,10]$ ) and glycine, subsequently cleaved by a $\mathrm{Cu}^{2+}-$, ascorbic acid- and $\mathrm{O}_{2}-$

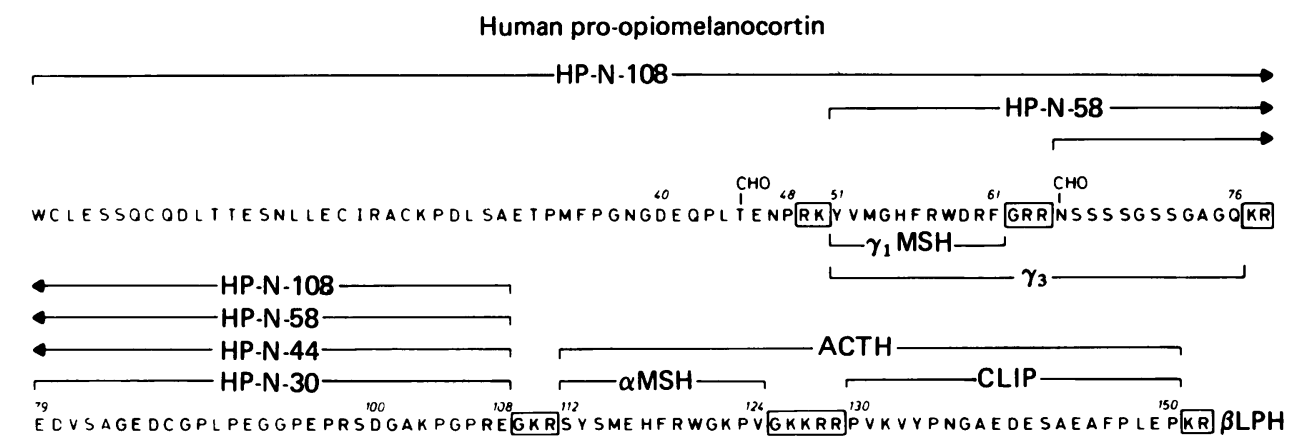

Fig. 1. Primary structure of human pro-opiomelanocortin

The amino acid sequence shown was deduced from the cDNA sequence of human pro-opiomelanocortin [6,7]. The dibasic amino acids and the glycine residues, $N$-terminal to these putative cleavage sites, are boxed. The peptide products generated, assuming that only dibasic amino acids are cleaved, are indicated, particularly emphasizing the amidated peptides. $\gamma_{2} \mathbf{M S H}$ contains the $C$-terminal glycine-extended $\gamma_{1}$ MSH peptide. Abbreviations: CLIP, corticotropin-like intermediate-lobe peptide; $\beta$ LPH, $\beta$-lipotropin.

Abbreviations used: POMC, pro-opiomelanocortin; ACTH, adrenocorticotropic hormone (corticotropin); $\alpha$-, $\beta$ - and $\gamma$-MSH, $\alpha$-, $\beta$ - and $\gamma$ melanocyte-stimulating hormone (melanotropin) respectively; HP-N, amidated hinge peptide(s).

* To whom correspondence should be addressed. 
dependent enzyme leaving $X_{1} \alpha$-carboxyamidated [11,12]. The production of $\alpha \mathrm{MSH}$ and its acetylation has been examined in several species including man [e.g. 13-15], but there are only a few descriptions of amidated $\gamma \mathrm{MSH}$ and HP-N in humans $[8,16-18]$. The purpose of this study was to characterize all the $\alpha$-amidated POMCderived peptides in normal human pituitary and to outline a processing pathway for these peptides.

\section{MATERIALS AND METHODS}

\section{Materials}

ACTH-(1-39), АCTH-(7-38), ACTH-(18-39), ACTH-(1-17), $N$-acetyl-ACTH-(1-17), ACTH-(1-14), $N$-acetyl-ACTH-(1-14), $\alpha \mathrm{MSH}$, desacetyl- $\alpha \mathrm{MSH}$ [ACTH-(1-13)- $\mathrm{NH}_{2}$ ] $\gamma_{1} \mathrm{MSH}, \gamma_{2} \mathrm{MSH}, \beta$-endorphin, $\beta \mathrm{MSH}$, sulphated and non-sulphated CCK -8 and gastrin17 were obtained from Bachem (Bubendorf, Switzerland), CRB (Cambridge, U.K.) or Peninsula (Belmont, CA, U.S.A.). ACTH-(1-16) was kindly donated by CIBA-Geigy (Basel, Switzerland). An HP-N analogue, D-Tyr-Ala-Lys-Pro-Gly-Pro-Arg-Glu- $\mathrm{NH}_{2}$, and a glycine-extended analogue, D-Tyr-Ala-Lys-Pro-Gly-ProArg-Glu-Gly, were synthesized by CRB. Only the $N$ terminal amino acid was in the D-form; the remaining amino acids were L-forms. These sequences are identical to the 7 or $8 C$-terminal amino acids in human hinge peptide, respectively. The D-form of tyrosine was included to prevent degradation of the peptides by aminopeptidases. The purity of peptides was controlled by h.p.l.c. as described below and by amino acid analysis on an LKB 4400 analyser (Biochrom, Cambridge, U.K.) after hydrolysis in $6 \mathrm{M}-\mathrm{HCl}$ at $110^{\circ} \mathrm{C}$ for $24 \mathrm{~h}$. Carrierfree $\mathrm{Na}^{125} \mathrm{I},{ }^{22} \mathrm{NaCl}$ and ${ }^{125} \mathrm{I}$-albumin were obtained from Amersham (Amersham, Bucks., U.K.) and Iodogen (1,3,4,6-tetrachloro-3 $\alpha, 6 \alpha$-diphenylglycouril) was from Pierce (Rockford, IL, U.S.A.). Bio-Gel P10 was purchased from Bio-Rad (Richmond, CA, U.S.A.), concanavalin A-Sepharose from Pharmacia (Uppsala, Sweden), Sep-Pak from Waters Associates (Milford, MA, U.S.A.) and $\mathrm{C}_{18}$-Nucleosil 300/5 from MacheryNagel (Düren, West Germany). The $C_{18}$-Lichrosorb used for tracer purification was from Merck (Darmstadt, West Germany).

\section{Radioimmunoassays}

Radioimmunoassays for ACTH-(1-39), ACTH-(114), $\alpha \mathrm{MSH}, \gamma_{1} \mathrm{MSH}$ and $\gamma_{2} \mathrm{MSH}$ have been described previously $[19,20]$. Briefly, the ACTH-(1-39) radioimmunoassay was specific for the ACTH-(13-17) sequence and recognized ACTH-(1-17) and ACTH-(1-16), with an $\mathrm{ED}_{50}$ of $100 \%$, and ACTH-(1-16), with an $\mathrm{ED}_{50}$ of $32 \%$. This assay did not recognize ACTH-(1-14) or $\alpha \mathrm{MSH}$ or any of the other peptides listed under 'Materials'. The ACTH-(1-14) radioimmunoassay recognized ACTH-(1-39), ACTH-(1-17), ACTH-(1-16) and $\alpha \mathrm{MSH}$ with an $\mathrm{ED}_{50}$ of $1.6 \%, 1.5 \%, 2.9 \%$ and $2.1 \%$, respectively. The $\alpha \mathrm{MSH}$ radioimmunoassay was completely specific for the amidated group of $\alpha \mathrm{MSH}$. The two latter assays did not recognize any of the other peptides listed under 'Materials' and were not influenced by $N$-terminal modifications [19]. The $\gamma_{1} \mathrm{MSH}$ radioimmunoassay was specific for the $C$-terminal amidated group and recognized $\gamma_{2} \mathrm{MSH}$ with an $\mathrm{ED}_{50}$ of less than $0.05 \%$. The $\gamma_{2}$ MSH-radioimmunoassay recognized $\gamma_{1} \mathrm{MSH}$ with an $\mathrm{ED}_{50}$ of less than $0.02 \%$. None of the latter assays recognized the previously listed peptides [20]. Radioimmunoassay for HP-N was developed and performed as described for the other peptides [19]. The short HP-N analogue (see the Materials section) was coupled to bovine serum albumin by carbodi-imide, and antibodies were raised in rabbits [19]. The antiserum used in the assay was specific to the $C$-terminal amidated group of hinge peptides and recognized synthetic glycineextended hinge peptide with an $\mathrm{ED}_{50}$ of less than $0.02 \%$. No other POMC-derived peptides were recognized by the assay. ${ }^{125} \mathrm{I}$-hinge peptide was purified on $\mathrm{C}_{18}{ }^{-}$ Lichrosorb at $50^{\circ} \mathrm{C}$ in $0.1 \%$ trifluoroacetic acid and eluted in 40 min with an 18-23.5\% methanol gradient in $0.1 \%$ trifluoroacetic acid. Labelled peptide was stabilized by adding $100 \mu \mathrm{l}$ of bovine serum albumin to $0.5 \mathrm{ml}$ fractions collected and stored at $4{ }^{\circ} \mathrm{C}$. Sensitivity of the assays varied from $1 \mathrm{fmol}$ to $5 \mathrm{fmol}$.

\section{Extraction of pituitaries}

Pituitary tissue was obtained $6-16 \mathrm{~h}$ post-mortem from patients who died from non-endocrine diseases. The pituitaries were kept on ice and the anterior lobes were separated from the posterior lobes and the remnants of the intermediate lobe. These were subsequently frozen in liquid $\mathrm{N}_{2}$, cut into pieces, and boiled for $20 \mathrm{~min}$ in water $(10 \mathrm{ml} / \mathrm{g})$. The boiled pituitaries were homogenized in a Potter-Elvehjem homogenizer and centrifuged. The pellet obtained was extracted in an equal volume of $0.5 \mathrm{~m}$-acetic acid for $30 \mathrm{~min}$ at room temperature and centrifuged. The water and acetic acid extracts were stored at $-20^{\circ} \mathrm{C}$.

\section{Gel filtration}

Water and acetic acid extracts were pooled and subjected to gel filtration on a $1.1 \mathrm{~cm} \times 96 \mathrm{~cm}$ column of Bio-Gel P10. Peptides were eluted by $0.5 \mathrm{M}$-acetic acid at a flow rate of $10 \mathrm{ml} / \mathrm{h}$ at ambient temperature. Fractions $(1 \mathrm{ml})$ were collected and stored at $-20^{\circ} \mathrm{C}$. The columns were calibrated with ${ }^{125} \mathrm{I}$-albumin, ${ }^{22} \mathrm{NaCl}$ and synthetic peptides.

\section{H.p.l.c.}

All h.p.l.c. was performed on $\mathrm{C}_{18}$-Nucleosil columns at $50{ }^{\circ} \mathrm{C}$. Three gradient systems were used. (I) Buffer A, $10 \mathrm{~mm}$-ammonium acetate (pH 4.1); buffer B, $90 \%$ methanol in the same buffer. Gradient: $0-3 \mathrm{~min}, 5 \%$ buffer B; 3-5 min, 5-37\% buffer B; 5-30 min, $37 \%$ buffer $\mathrm{B} ; 30-31 \mathrm{~min}, 37-90 \%$ buffer $\mathrm{B} ; 31-38 \mathrm{~min}$, $90 \%$ buffer B. (II) Buffers as in (I). Gradient: 0-3 min, $5 \%$ buffer $\mathrm{B} ; 3-33 \mathrm{~min}, 5-90 \%$ buffer $\mathrm{B} ; 33-40 \mathrm{~min}$, $90 \%$ buffer B. (III) Buffer A, 10 mM-heptafluorobutyric acid; buffer B, $90 \%$ methanol in 10 mM-heptafluorobutyric acid. Gradient as in (II). The columns were eluted with a flow rate of $1.0 \mathrm{ml} / \mathrm{min}$ and $0.5 \mathrm{ml}$ of fractions were collected, evaporated and stored at $-20^{\circ} \mathrm{C}$. Each sample was reconstituted in $0.5 \mathrm{ml}$ of $0.5 \mathrm{M}$-acetic acid before assay. The columns were calibrated using synthetic peptides.

\section{Concanavalin A-Sepharose}

Peptides were dissolved in $0.5 \mathrm{ml}$ of $25 \mathrm{~mm}$-Tris (pH 7.0) containing $0.5 \mathrm{M}-\mathrm{NaCl}, 1.0 \mathrm{~mm}-\mathrm{CaCl}_{2}$ and $1.0 \mathrm{~mm}-\mathrm{MgCl}_{2}$ and applied to an $0.5 \mathrm{ml}$ column of concanavalin A-Sepharose. The column was washed in buffer at room temperature and eluted by a stepwise gradient of $0.1 \mathrm{M}$ - and $0.5 \mathrm{M}-\alpha$-methyl D-mannoside. 
Fractions $(0.5 \mathrm{ml})$ were collected and assayed after addition of $100 \mu \mathrm{l}$ of $1 \%$ bovine serum albumin.

\section{Sequence analysis}

Purified peptides were sequenced on a $470 \mathrm{~A}$ protein sequencer (Applied Biosystems, CA, U.S.A.) and the phenylthiohydantoin (PTH) derivatives were identified by h.p.l.c. on a Hewlett Packard 1090 liquid chromatograph using a PTH- $\mathrm{C}_{18}$ column $(2.1 \mathrm{~mm} \times 220 \mathrm{~mm})$ and a sodium acetate buffer/acetonitrile gradient elution system (both from Applied Biosystems).

\section{Calculations}

Correction for cross-reactivity of ACTH-(1-39), ACTH-(1-17), ACTH-(1-16) and $\alpha \mathrm{MSH}$ in the ACTH(1-14) radioimmunoassay, was made to all values in the Tables and Figures. The total amount of POMC and processed POMC was calculated as the sum of ACTH(1-39), ACTH-(1-14) and $\alpha$ MSH immunoreactivity, which are derived from the same region in POMC and includes all the known forms of peptides in this region.

\section{RESULTS}

\section{Pituitary extracts}

Pituitaries were initially divided into anterior and neurointermediate lobes, the latter including the remnants of the intermediate lobe. However, no difference in the pattern of the extracted peptides could be detected. The peptide content was therefore calculated for whole pituitaries (Table 1). The peptide content varied considerably, especially the ACTH-(1-39) content. The content of the individual peptides relative to total POMC also varied. Table 1 indicates the amount of amidated peptides relative to the sum of amidated and glycineextended peptides, i.e. total amount of processed peptides with the exception of HP-N because a radioimmunoassay for glycine-extended hinge peptide is not available. The HP-N content was 2-3-fold or more greater than the $\alpha \mathrm{MSH}$ and $\gamma_{1} \mathrm{MSH}$ content.

\section{Gel chromatography}

Pooled water and acetic acid extracts were applied to Bio-Gel P10 columns (Fig. 2). The recovery from the column of HP-N and ACTH was $22 \%$ and $31 \%$, respectively, in the chromatogram shown in Fig. 2. The ratio HP-N/ACTH eluted from the column was 0.99 compared with 1.47 for the applied extract. More than $95 \%$ of the ACTH-(1-39) immunoreactivity eluted at the same elution position as synthetic ACTH-(1-39); the remaining immunoreactivity eluted as high-molecularmass ACTH. A small shoulder was observed on the descending part of the ACTH-(1-39) peak which corresponds to the elution position of ACTH-(1-16) and ACTH-(1-17). ACTH-(1-14) and $\alpha \mathrm{MSH}$ immunoreactivity eluted at greater $K_{\mathrm{av}}$. values than the synthetic peptides. Two main peaks were observed at $K_{\text {av }}$ 1.1-1.2 and $1.4-1.5$, respectively. This pattern was identical for all extracts investigated.

The HP-N eluted in three distinct peaks. All the pituitaries showed a similar pattern as was also found when anterior and neurointermediate lobes were chromatographed separately. The relative distribution of the indicated peaks was I ( $30 \%)$, II $(55 \%)$ and IV (15\%). The elution pattern of $\gamma_{1} \mathrm{MSH}$ immunoreactive peptides was heterogeneous, but two main peaks could be distinguished: the first in, or just after, the void volume of the column and the second at $K_{\text {av. }} 0.35-0.45$. No immunoreactivity was observed at the elution position of synthetic low-molecular-mass $\gamma_{1}$ MSH or $\gamma_{2}$ MSH. Fractions collected at the elution position of these peptides were pooled and concentrated. However, no $\gamma_{1} \mathrm{MSH}$ or $\gamma_{2} \mathrm{MSH}$ immunoreactivity could be detected in these pools.

\section{H.p.l.c. and sequence analysis}

The ACTH-(1-14) and $\alpha \mathrm{MSH}$ immunoreactivity in Fig. 2 were pooled as indicated, purified on Sep-Pak [19], and subjected to h.p.l.c. in buffer system I. $\alpha \mathrm{MSH}$ immunoreactivity eluted in two main peaks corresponding to the elution position of synthetic $\alpha \mathrm{MSH}$ and desacetyl- $\alpha$ MSH [ACTH-(1-13)- $\mathrm{NH}_{2}$ ] (Fig. 3). These

Table 1. Absolute and relative content of pro-opiomelanocortin-derived peptides in normal human pituitary

The range of peptide content was calculated from the water and acetic acid extracts from five human pituitaries obtained at autopsy. Peptide content in anterior and neurointermediate lobe with attached remnants of intermediate lobe were initially determined separately. The results were, however, pooled as no significant difference in relative content and molecular forms of the peptides were detected. $T_{\text {Pomc }}$ was calculated as the sum of ACTH-(1-39), ACTH-(1-14) and $\alpha$ MSH immunoreactivity. $T_{\gamma \mathrm{MSH}}$ was the sum of $\gamma_{1} \mathrm{MSH}$ and $\gamma_{2} \mathrm{MSH}$ immunoreactivity. Note that the ACTH-(1-39) content may have been underestimated (see the Discussion section).

\begin{tabular}{|c|c|c|c|c|c|c|c|c|}
\hline & \multicolumn{7}{|c|}{ Absolute content (pmol/pituitary) } & \\
\hline & АCTH-(1-39) & $\begin{array}{c}\text { ACTH- } \\
(1-14)\end{array}$ & $\alpha \mathrm{MSH}$ & $\gamma_{1} \mathrm{MSH}$ & $\gamma_{2} \mathrm{MSH}$ & HP-N & Total POMC & \\
\hline & $3151-43517$ & $538-1842$ & $34-134$ & $45-638$ & $60-230$ & $30756-64808$ & $4185-44188$ & \\
\hline \multicolumn{9}{|c|}{ Relative content $(\%)$} \\
\hline ACTH-(1-39) & АCTH-(1-14) & $\alpha \mathrm{MSH}$ & $\underline{\gamma_{1} \mathrm{MSH}}$ & $\underline{\gamma_{2} \mathrm{MSH}}$ & HP-N & $\alpha \mathrm{MSH}$ & $\gamma_{1} \mathrm{MSH}$ & $\underline{T_{\gamma \mathrm{MSH}}}$ \\
\hline$\overline{T_{\text {POMC }}}$ & $\overline{T_{\text {ромс }}}$ & $\overline{T_{\text {Ромс }}}$ & $\overline{T_{\text {POMC }}}$ & $\overline{T_{\text {Ромс }}}$ & $\overline{T_{\text {ромс }}}$ & 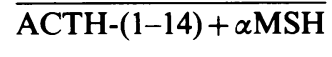 & $\overline{\gamma_{1} \mathrm{MSH}+\gamma_{2} \mathrm{MSH}}$ & $\overline{T_{\text {PONC }}}$ \\
\hline $75.3-98.5$ & $1.2-23.4$ & $0.27-1.31$ & $0.10-5.10$ & $0.32-1.84$ & $147-1077$ & $1.8-19.9$ & $14.4-73.5$ & $0.4-7.0$ \\
\hline
\end{tabular}



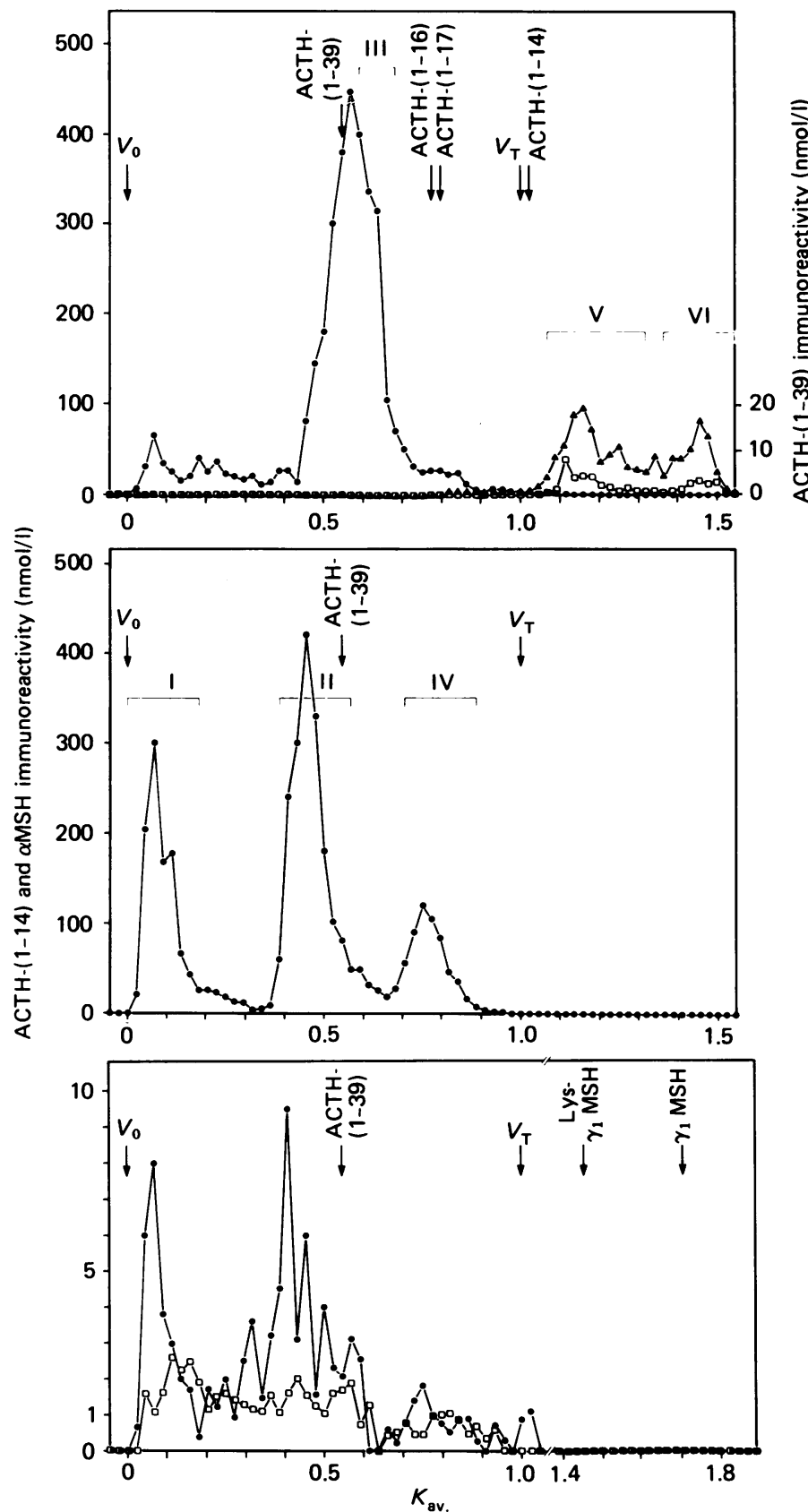

Fig. 2. Gel chromatography on Bio-Gel P10 of POMC-derived peptides from normal human pituitary

Water and acetic acid extracts were pooled and applied to a $1.1 \mathrm{~cm} \times 96 \mathrm{~cm}$ column of Bio-Gel P10. Peptides were eluted using $0.5 \mathrm{M}$-acetic acid at room temperature and $1.0 \mathrm{ml}$ fractions were collected. ACTH-(1-39) immunoreactivity (O) (upper part) is indicated on the left scale and ACTH-(1-14) ( $(\Delta)$ and $\alpha \mathrm{MSH}$ immunoreactivity $(\square)$ are indicated on the right scale. The pools indicated were further purified by h.p.l.c. (Figs. 3 and 4). The middle part of the Figure shows the elution of HP-N. The indicated pools were further purified by h.p.l.c. (pools II and III, Fig. 4). The lower part of the Figure shows the elution of $\gamma_{1} \mathrm{MSH}$ immunoreactivity (O) and $\gamma_{2} \mathrm{MSH}$ immunoreactivity ( $\square$ ). No $\gamma_{1} \mathrm{MSH}$ or $\gamma_{2} \mathrm{MSH}$ immunoreactivity could be detected at the elution position of synthetic $\gamma_{1} \mathrm{MSH}$ or $\gamma_{2} \mathrm{MSH}$. Note the change in abscissa values in the lower part of the Figure. The column was calibrated with ${ }^{125} \mathrm{I}$-albumin $\left(V_{0}\right),{ }^{22} \mathrm{NaCl}\left(V_{\mathrm{T}}\right)$ and synthetic peptides. $K_{\text {av. }}=V_{\mathrm{e}}-V_{0} / V_{\mathrm{T}}-V_{0}$.

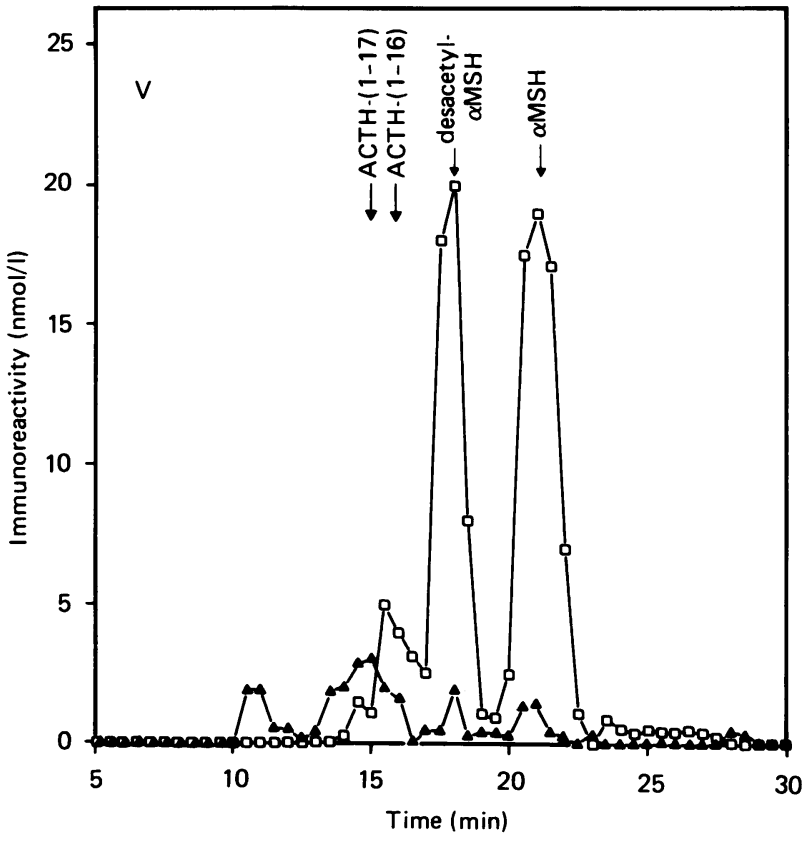

Fig. 3. H.p.l.c. of ACTH-(1-14) and $\alpha$ MSH immunoreactivity from normal human pituitary

Pool V (Fig. 2) was chromatographed on $\mathrm{C}_{18}$-Nucleosil after purification on Sep-Pak. Buffer system I was used (see the Methods section) and peptides were eluted using $37 \%$ buffer B [33.3\% (v/v) methanol in $10 \mathrm{~mm}$-ammonium acetate, pH 4.1]. Only the part of the chromatogram containing ACTH-(1-14) (A) and $\alpha \mathrm{MSH}(\square)$ immunoreactivity is shown. A similar pattern was obtained by chromatography of pool VI from Fig. 2. The column was calibrated using synthetic peptides as indicated.

two peaks account for about $90 \%$ of the total $\alpha \mathrm{MSH}$ immunoreactivity. The remainder of the $\alpha \mathrm{MSH}$ immunoreactivity eluted before the desacetyl- $\alpha$ MSH peak, corresponding to oxidized desacetyl- $\alpha \mathrm{MSH}$. No peak corresponding to $N O$-diacetyl- $\alpha \mathrm{MSH}$ was observed at 23-25 min [19]. ACTH-(1-14) (18 min) and $N$-acetylACTH-(1-14) (21 min) were detected, but the main ACTH-(1-14) immunoreactivity was detected in a peak eluting at $15 \mathrm{~min}$ which was before the elution position of ACTH-(1-16). There was no significant difference in the elution patterns of pools $\mathrm{V}$ and VI indicated in Fig. 2.

Fig. 4 shows the elution of the ACTH-(1-39) and HP$\mathrm{N}$ immunoreactivity of the pools indicated in Fig. 2. Ammonium acetate was used as the counter ion in these chromatograms (buffer system II). ACTH-(1-39) immunoreactivity eluted at a position corresponding to ACTH-(1-39) and ACTH-(7-38) which has been identified by Li et al. [21] (Fig. 4, upper panel). Small peaks corresponding to the elution position of ACTH-(1-16) and ACTH-(1-17) were detected (Fig. 4, middle and lower panel). The HP-N from pool II (Fig. 2) eluted in a single peak (Fig. 4, upper panel). By contrast, the HP-N in pool IV eluted in two distinct peaks (lower panel). In the latter, a small amount of immunoreactivity eluted at the same position as the material in pool II.

The pools indicated in Fig. 4 were further purified by h.p.l.c. in buffer system III. More than $95 \%$ of the HP$\mathrm{N}$ in pool II $a$ eluted as a single peak (Fig. 5). Pool IV $b$ 

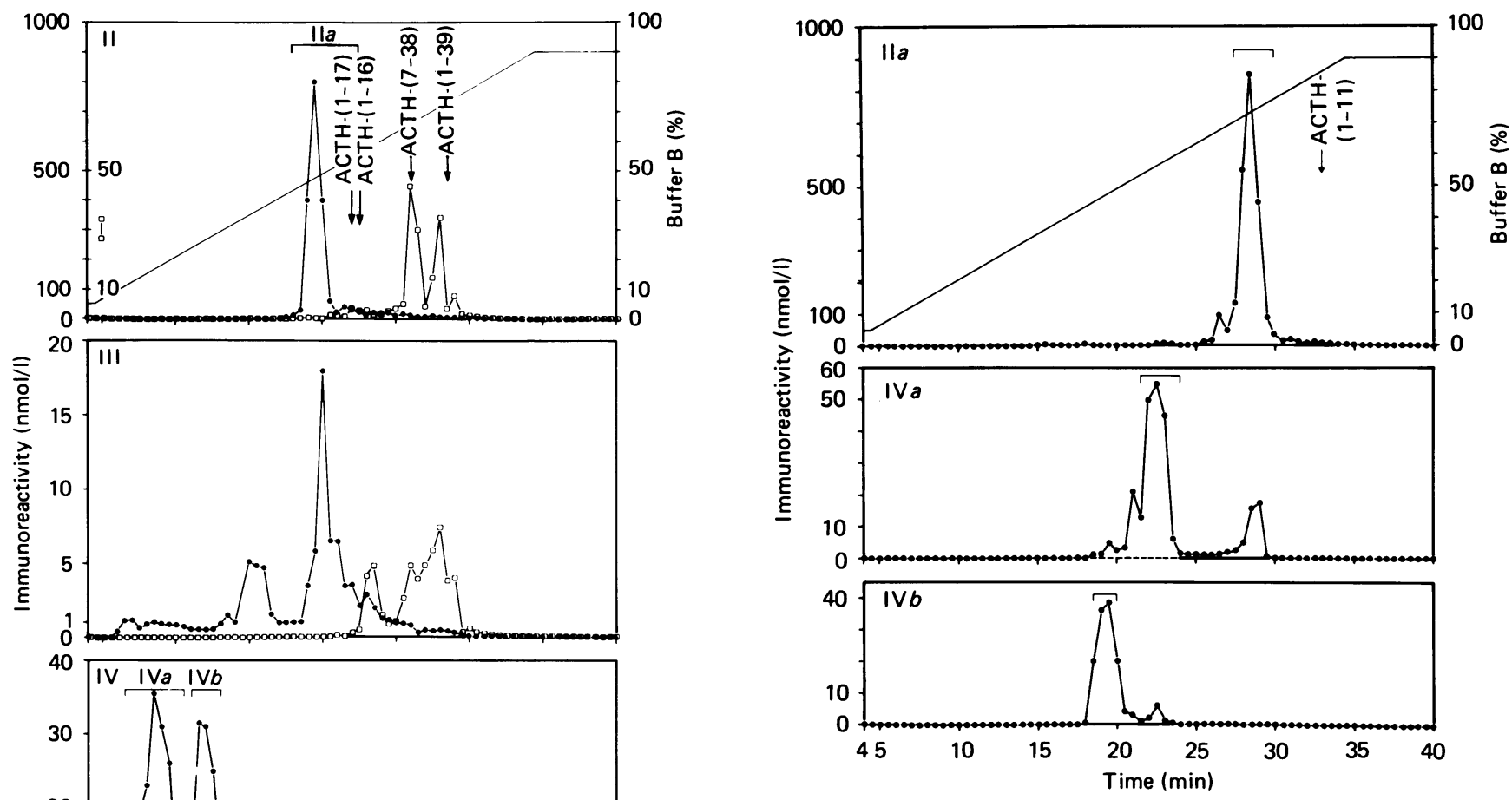

Fig. 5. H.p.l.c. of HP-N from normal human pituitary

The pools indicated in Fig. 4 were chromatographed on $\mathrm{C}_{18}$-Nucleosil in buffer system III (see the Methods section). Note the difference in the scales. Buffer B was $90 \%$ methanol in $10 \mathrm{~mm}$-heptafluorobutyric acid. Fractions were pooled as indicated and the HP-N were sequenced (Fig. 6).

Fig. 4. H.p.l.c. of immunoreactive ACTH-(1-39) and HP-N from human pituitary

Pools II, III and IV (Fig. 2) were chromatographed with $\mathrm{C}_{18}$-Nucleosil in buffer system II (upper, middle and lower panels respectively). Note the difference in the scales. Buffer B was $90 \%$ methanol in $10 \mathrm{~mm}$-ammonium acetate. The column was calibrated with the synthetic peptides indicated. Pools of peptides were prepared as indicated and were rechromatographed (Fig. 5). ( $\square$ ), ACTH-(1-39); (O), HP-N.

eluted essentially as one peak, while pool IV $a$ contained an additional peak eluting at the same position as the main peak in II $a$. This was not a contaminant from pool II, as the peptides chromatographed in IV $a$ were completely separated from the peptides in II $a$ by h.p.l.c. chromatography in buffer system II (Fig. 4). The two main peaks in IV $a$ and IV $b$ were eluted in the reverse order of the elution pattern in Fig. 4. The peaks indicated in Fig. 5 were pooled and partly sequenced. The sequence obtained from pool II $a$ is shown in Fig. 6. The peptide was not completely pure, but a sequence identical to the first 15 amino acids in HP-N-30 [POMC-(79-108), Fig. 1] was easily identified and a small amount of HP-N-30 depleted of the $N$-terminal glutamate was probably present. The gap at number 9 (Fig. 6) most likely corresponds to a cysteine. Sequence analyses of pools IV $a$ and IV $b$ were unsuccessful, but sequence analyses of pool I (Fig. 2) showed a sequence identical to the initial eight amino acids in HP-N-30.

The elution of the same peptides by P10 chromato-

graphy at different elution positions and the appearance of the peak eluting at 28.5 min in Fig. 5 (IV $a$ ) suggests a conjugation by disulphide linkage had occurred. This was confirmed by treatment of pool I and II with $\beta$ mercaptoethanol and elution of the peptides from BioGel P10 with $0.5 \mathrm{M}$-acetic acid containing $0.1 \% \beta$ mercaptoethanol. Under these conditions all the hinge peptide from pool II and more than $98 \%$ from pool I eluted as low-molecular-mass hinge peptide. Small amounts of HP-N from pool I still eluted in the void volume of the column. This probably represents HP-N-108, but the presence of glycosylated forms of HP-N-44 or HP-N-58, could not entirely be excluded.

\section{Concanavalin A-Sepharose chromatography}

The pool indicated by I in Fig. 2 was chromatographed on concanavalin A-Sepharose. The fraction of ACTH and $\gamma_{1} \mathrm{MSH}$ immunoreactivity absorbed was $65 \%$ and $88 \%$ respectively (results not shown). Too low an amount of high-molecular-mass HP-N was present for determination of the degree of glycosylation.

\section{DISCUSSION}

The results show that normal human pituitary contains all the amidated POMC products that can be extracted from the POMC sequence (Fig. 1). The content of $\alpha \mathrm{MSH}$ and $\gamma_{1} \mathrm{MSH}$ and their glycine-extended precursors were low and variable, while the amount of HP-N was up to 2-3 or more orders of magnitude greater than $\alpha \mathrm{MSH}$ and $\gamma_{1} \mathrm{MSH}$. 


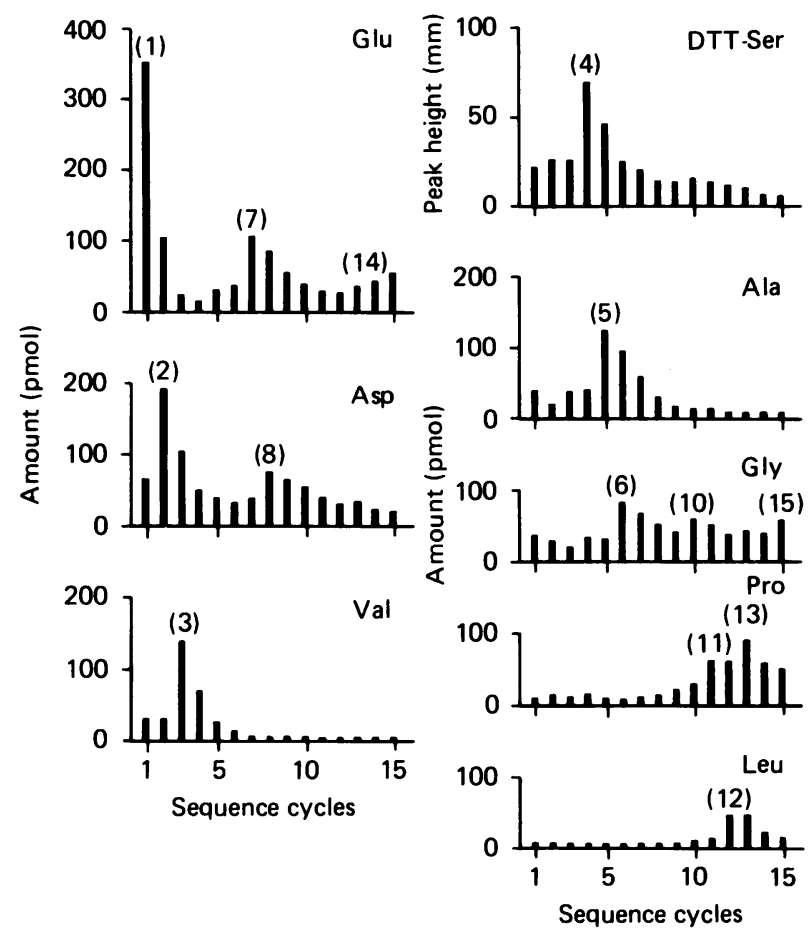

Fig. 6. Sequence analysis of HP-N

The first 15 amino acids of the sequence analysis of the pool indicated in the upper panel in Fig. 5 is shown. This sequence is identical to the $N$-terminal sequence of HP-N30. Amino acid number 9 is cysteine in the cDNA-deduced sequence, but could not be identified in this system. The sequences of the other two pools indicated in Fig. 5 are discussed in the text (see the Results section). Abbreviation: DTT-Ser, dithiothreitol-trapped PTH-Ser.

The principal forms of the $\alpha$-amidated peptides found were $\alpha \mathrm{MSH}$, low-molecular-mass HP-N-30 and $\gamma_{1} \mathrm{MSH}$ analogues of exclusively high molecular mass (Fig. 1).

Previous studies have established the initial cleavage of POMC to ACTH, $\beta$-lipotropin and $16 \mathrm{kDa} N$-terminal fragments as well as the further processing of ACTH to $\alpha$ MSH as shown in Fig. 7 [1]. The processing pathway of the $N$-terminal fragment HP-N-108 is only tentative because dynamic studies on this part of the precursor are lacking. However, several findings support this pattern of processing. First, $N$-POMC-(1-76) is the only $\gamma_{3} \mathrm{MSH}$ immunoreactivity (Fig. 1) detected in man [22,24]. This would suggest that no cleavage takes place at POMC(49-50), a conclusion supported by detection of only high-molecular-mass forms of $\gamma_{1} \mathrm{MSH}$ (Fig. 2). If cleavage at POMC-(49-50) does occur, low-molecularmass $\gamma_{1}$ MSH would have been expected to be found. Furthermore, only two forms of HP-N could be detected, i.e. HP-N-108 and HP-N-30, and modified analogues. These findings suggest that the principle cleavage products of the $N$-terminal POMC are $N$-POMC-(1-76) and HP-N-30 (Fig. 7).

This model implicates that the most likely source of high-molecular-mass $\gamma_{1} \mathrm{MSH}$ is $N$-POMC-(1-76). Alternatively, this $\gamma_{1} \mathrm{MSH}$ immunoreactivity could be derived directly from HP-N-108. The lack of detection of HP-N44, which would be produced concomitantly, cannot exclude this possibility, as HP-N-44 could have been cleaved very quickly to HP-N-30 (Fig. 7). In fact, both

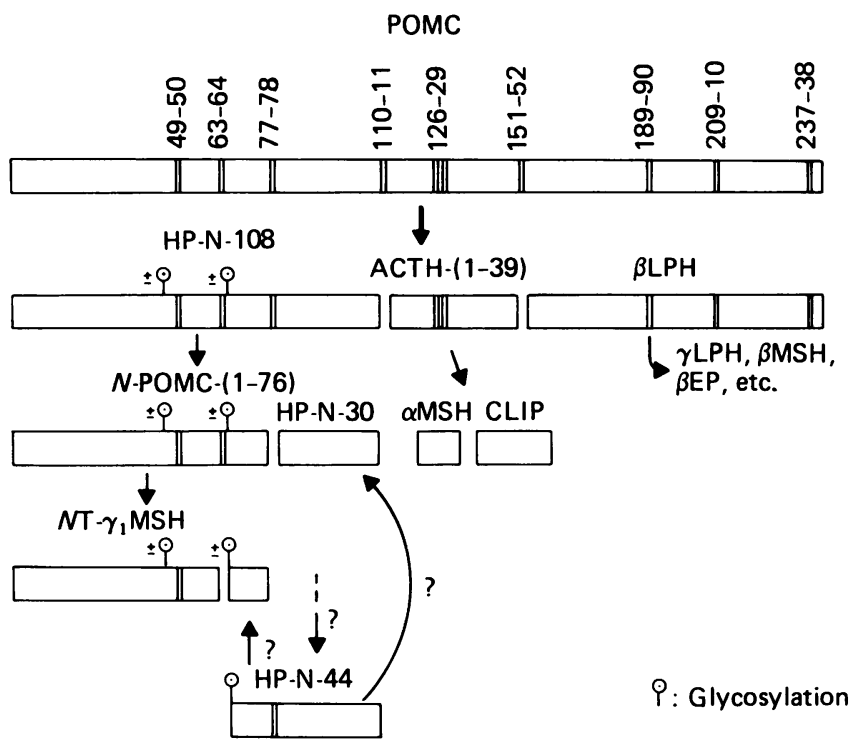

Fig. 7. Processing of pro-opiomelanocortin in normal human pituitary

The cleavage pattern shown was deduced from the molecular forms of the peptides identified as described in the text and from previously published results [1]. All glycine-extended basic amino acid extended forms including ACTH-(1-15), ACTH-(1-16), ACTH-(1-17) and ACTH-(7-38) have been omitted. The $N$-terminal $16 \mathrm{kDa}$ POMC fragment is therefore only represented by HP-N108 in the Figure. The presence of HP-N-44 is only suggested, as it could not be definitely identified. The cleaved POMC-(65-76) has not been determined, but is a natural product produced when $N$-terminal-extended $\gamma_{1} \mathrm{MSH}\left(N \mathrm{~T}-\gamma_{1} \mathrm{MSH}\right)$ is produced. Apparently no lowmolecular-mass $\gamma_{1}$ MSH is produced. For details of sequence see Fig. 1. No attempt was made to differentiate the processing pathways in the corticotrophs and the $\alpha \mathrm{MSH}$ cells. Abbreviations: $\beta \mathrm{EP}, \beta$-endorphin; CLIP, corticotropin-like intermediate-lobe peptide; $\beta \mathrm{LPH}, \beta$ lipotropin.

pathways could be functioning in different sub-groups of ACTH cells $[25,26]$. Nevertheless, as far as HP-N is concerned, the latter pathway would only be a minor contribution to the production of HP-N as judged by the small amounts of $\gamma_{1} \mathrm{MSH}$ and $\gamma_{2} \mathrm{MSH}$ immunoreactivity present.

Small amounts of low-molecular-mass $\gamma_{1} \mathrm{MSH}$ (and $\left.\gamma_{2} \mathrm{MSH}\right)$ were detected in the neurointermediate lobe of the pig pituitary but not in the anterior lobe [20]. This indicates that cleavage at POMC-(49-50) does occur in the intermediate lobe, but not in the anterior lobe. The intermediate lobe in adult human pituitary is a nonfunctional remnant of the intermediate lobe in other mammals [27], but a few $\alpha$ MSH-producing cells can be detected in the anterior lobe by immunohistochemistry [26]. However, these $\alpha \mathrm{MSH}$-cells were too scarce to produce detectable amounts of low-molecular-mass $\gamma \mathrm{MSH}$. In accordance with this, no HP-N-58 or $\gamma_{3} \mathrm{MSH}$ [22-24] were detected (Fig. 1).

The anterior lobe is rich in $\alpha$-amidating activity [12], but it has been shown that the efficiency of cleavage of the $C$-terminal glycine is dependent on the amino acid being amidated [11]. Glutamate, as present in hinge 
peptide, is a poor substrate, but actually HP-N is by far the most abundant amidated peptide in the human pituitary. This suggests that the content of $\alpha$-amidated peptides is mainly determined by the extent of endopeptidic cleavage and only to a lesser extent by the $\alpha$ amidation process itself. This is supported by the processing of cholecystokinin in human pituitary [28].

It was somewhat surprising to find that the main part of the HP-N was conjugated by disulphide linkages (peaks I and II, Fig. 2). The conjugation was not a consequence of post-mortem modification, because the same degree of conjugation was detected in pituitary tumours frozen immediately after surgery (Fenger \& Johnsen, unpublished results). Although it was not possible to define the molecules conjugated to HP-N-30, the consistent elution of peak II by gel chromatography and h.p.l.c., strongly suggests that only one molecular species conjugates to HP-N-30. The sequence data of purified peak II, suggest that HP-N-30 itself or its $C$ terminal glycine-extended precursor are the most likely candidates. Conjugation to an $N$-terminal-blocked cysteine-containing peptide cannot be excluded, since such a peptide would have escaped the sequence analysis. The HP-N-30 in peak I could be conjugated to any $16 \mathrm{kDa} N$-POMC fragment, but any cysteine-containing peptide or protein would be a candidate. Further experiments are needed to elucidate the exact conjugation of HP-N-30 and its significance.

All the HP-N/POMC ratios were greater than 1.0 (Table 1). This could be due to an underestimation of the ACTH-(1-39) content in the extracts. As only one POMC gene has been detected [6,7,29], and no alternative splicing of the mRNA has been demonstrated, the most probable reason for this low ACTH-(1-39) content is autolysis in the post-mortem tissue [30]. This is supported by HP-N/POMC ratios of not greater than 0.6 in pituitaries obtained on surgery and immediately frozen (Fenger \& Johnsen, unpublished results). However, except for the calculation of the relative values of $\alpha$-amidated peptides being too high, the underestimation of the ACTH-(1-39) content does not affect the proposed pathway of processing discussed above.

A physiological function for the pituitary-derived peptides has only been established for ACTH-(1-39) $[31,32]$. It has been suggested that $\gamma \mathrm{MSH}$-related peptides are involved in steroidogenesis in the adrenal gland [33-39] at least in synergism with ACTH-(1-39). However, the physiological effects of pituitary-derived amidated peptides in humans essentially remains to be determined.

Stana Jirus is acknowledged for skilful technical assistance and Else Krone for typing this manuscript. Thanks also go to Professor J. F. Rehfeld and Dr. Mayread O'Hara for helpful and inspiring discussions. This work was supported by grants from the Danish Cancer Foundation, Skovgaards Foundation, Petrus Andersens Foundation and A. P. Møllers Foundation.

\section{REFERENCES}

1. Eipper, B. A. \& Mains, R. E. (1980) Endocrine Rev. 1, $1-27$

2. Notake, M., Tobimatsu, T., Watanabe, Y., Takahashi, H., Mishina, M. \& Numa, S. (1983) FEBS Lett. 156, 67-71

3. Drouin, J. \& Goddman, H. M. (1980) Nature (London) 288, 610-613
4. Nakanishi, S., Inoue, A., Kita, T., Nakamura, M., Chang, A. C. Y., Cohen, S. N. \& Numa, S. (1979) Nature (London) 278, 423-427

5. Oates, E. \& Herbert, E. (1984) J. Biol. Chem. 259, 7421-7425

6. Chang, A. C. Y., Cochet, M. \& Cohen, S. N. (1980) Proc. Natl. Acad. Sci. U.S.A. 77, 4890-4894

7. Takahashi, H., Hakamato, Y., Watanabe, Y., Kikuno, R., Miyata, T. \& Numa, S. (1983) Nucleic Acids Res. 11, $6847-6858$

8. Seidah, N. G., Rochemont, J., Hamelin, J., Benjannet, S. \& Chrétien, M. (1981) Biochem. Biophys. Res. Commun. 102, 710-716

9. Mains, R. E., Eipper, B. A., Glembotski, C. C. \& Dores, R. M. (1983) Trends Neurosci. (Pers. Ed.) 6, 229-235

10. Fricker, L. D. (1985) Trends Neurosci. (Pers. Ed.). 8, 210-214

11. Bradbury, A. F., Finnie, M. D. A. \& Smyth, D. G. (1982) Nature (London) 298, 686-688

12. Eipper, B. A., Mains, R. R. \& Glembotski, C. C. (1983) Proc. Natl. Acad. Sci. U.S.A. 80, 5144-5148

13. Rudman, D., Chawla, R. K. \& Hollins, B. M. (1979) J. Biol. Chem. 254, 10102-10108

14. Glembotski, C. C. (1982) J. Biol. Chem. 257, 10493-10500

15. Vaudry, H., Jenks, B. G. \& van Overbeeke, A. P. (1983) Life Sci. 33, Suppl. I 97-100

16. Shibasaki, T., Ling, N. \& Guillemin, R. (1980) Biochem. Biophys. Res. Commun. 96, 1393-1399

17. Tanaki, I., Nakai, Y., Nakao, K., Oki, S., Yoshimasa, T. \& Imura, H. (1983) J. Clin. Endocrinol. Metab. 56, $1080-1083$

18. Ali-Rachedi, A., Ferri, G.-L., Varndell, I. M., van Noorden, S., Schot, L. P. C., Ling, N., Bloom, S. R. \& Polak, J. M. (1983) Neuroendocrinology 37, 427-433

19. Fenger, M. (1986) Biochem. J. 235, 715-722

20. Fenger, M. (1988) Regul. Pept., in the press

21. Li, C. H., Chung, D., Yamashiro, D. \& Lee, C. Y. (1978) Proc. Natl. Acad. Sci. U.S.A. 75, 4306-4309

22. Tanaka, I., Nakai, Y., Nakao, K., Oki, S., Fukata, J. \& Imura, H. (1981) Clin. Endocrinol. (London) 15, 353361

23. Bertagna, X., Seurin, D., Pique, L., Luton, J.-P., Bricaire, H. \& Girard, F. (1983) J. Clin. Endocrinol. Metab. 56, 489-495

24. Shibasaki, T., Masui, H., Sato, G., Ling, N. \& Guillemin, R. (1981) J. Clin. Endocrinol. Metab. 52, 350-353

25. Celio, M. R., Pasi, A., Bürgisser, E., Buetti, G., Höllt, V. \& Gramsch, C. (1980) Acta Endocrinol. 95, 27-40

26. Coates, P. J., Doniach, I., Hale, A. C. \& Rees, L. H. (1986) J. Endocrinol 111, 335-342

27. Osamura, R. Y. \& Watanabe, K. (1978) Cell Tissue Res. 194, 513-524

28. Rehfeld, J. F. (1987) Proc. Natl. Acad. Sci. U.S.A. 84, 3019-3023

29. Cochet, M., Chang, A. C. Y. \& Cohen, S. N. (1982) Nature (London) 297, 335-339

30. Allen, R. G., Orwoll, E., Kendall, J. W., Herbert, E. \& Paxton, H. (1980) J. Clin. Endocrinol. Metab. 51, 376-380

31. Simpson, E. R. \& Waterman, M. R. (1983) Can. J. Biochem. Cell Biol. 61, 692-707

32. John, M. E., John, M. C., Boggaram, V., Simpson, E. R. \& Waterman, M. R. (1986) Proc. Natl. Acad. Sci. U.S.A. 83, 4715-4719

33. Pedersen, R. C. \& Brownie, A. C. (1980) Proc. Natl. Acad. Sci. U.S.A. 77, 2239-2243

34. Pedersen, R. C., Brownie, A. C. \& Ling, N. (1980) Science 208, 1.044-1046

35. Seidah, N. G., Rochemont, J., Hamelin, J., Lis, M. \& Chrétein, M. (1981) J. Biol. Chem. 256, 7977-7984

Vol. 250 
36. Al-Dujaili, E. A. S., Hope, J., Estivariz, F. E., Lowry, P. J. \& Edwards, C. R. W. (1981) Nature (London) 291, 156-159

37. Estivariz, F. E., Iturriza, F., McLean, C., Hope, J. \& Lowry, P. J. (1982) Nature (London) 297, 419-422

Received 29 July 1987/19 October 1987; accepted 12 November 1987
38. Lowry, P. J., Silas, L., McLean, C., Linton, E. A. \& Estivariz, F. E. (1983) Nature (London) 306, 70-73

39. Sharp, B. \& Sowers, J. R. (1983) Biochem. Biophys. Res. Commun. 110, 357-363 